\title{
Linking Local Government and Demographics to Ecological Footprint
}

\author{
Muhammad Abduh $^{1, *}$, Dedik Budianta $^{2}$, Arinafril $^{3}$, Lili Erina $^{4}$ \\ ${ }^{1}$ Ilmu Pemerintahan, Program Pascasarjana, Universitas Tamansiswa, Palembang, Indonesia \\ ${ }^{2}$ Ilmu Lingkungan, Program Pascasarjana, Universitas Sriwijaya, Indonesia \\ ${ }^{2}$ Ilmu Lingkungan, Program Pascasarjana, Universitas Sriwijaya, Indonesia \\ 4Ilmu Administrasi Negara, Fakultas Ilmu Sosial dan Ilmu Politik, Universitas Sriwijaya, Indonesia \\ *Corresponding Author: abduh.muhammad@gmail.com
}

\section{Article history}

\begin{tabular}{llll} 
Received & Received in revised form & Accepted & Available online \\
02 July 2020 & 31 December 2020 & 31 December 2020 & 31 December 2020 \\
\hline
\end{tabular}

\begin{abstract}
To simplify the description of the damage phenomenon to the earth, the concept of ecological footprint can be used. This concept is not specifically built to calculate the destruction of the earth. This concept calculates how much space (on land and water) humans need to produce the resources they need including absorbing the waste they produce. This study calculates the ecological footprint in Palembang and its surroundings according to demographic factors and local government. To investigate the general pattern of ecological footprint and its determinants based on the respondents' reports, a survey was launched in October 2017. As a result, the average ecological footprint in Palembang Metropolitan and its surroundings is 0.591 global hectares (gha). The ecological footprint in Palembang Metropolitan and its surroundings is formed by 4 things, namely: diet and food choices, shelter/home life, transportation and lifestyle choices. The largest portion is given by diet and food choices (26.8 percent), while the smallest contribution is contributed by transportation ( 24.1 percent). Taking into account demographic factors, a high ecological footprint is owned by a group of male individuals, aged 30-39 years, highly educated, working, and after hearing and understanding climate change and ecological footprint. Finally, if observed according to the type of government, metropolitan cities have a high ecological footprint than others. Finally, the ecological footprint of Palembang as a metropolitan city is higher than the others.

Keywords: Demograpich, ecological footprint, Palembang Indonesia.
\end{abstract}

Abstrak (Indonesian): Untuk menyederhanakan gambaran fenomena kerusakan wajah bumi, dapat dipergunakan konsep jejak ekologi. Konsep ini tidak secara khusus dibangun untuk menghitung kurusakan wajah bumi. Konsep ini menghitung seberapa banyak ruang (di darat dan air) yang dibutuhkan manusia untuk menghasilkan sumber daya yang mereka perlukan termasuk menyerap limbah yang mereka hasilkan. Penelitian ini menghitung angka jejak ekologi Palembang dan sekitarnya dengan memperhatikan variasi menurut demografi dan tipe pemerintahan daerah. Untuk meneliti pola jejak ekologis dan faktor penentunya dilakukan survei yang dilaksanakan bulan Oktober 2017. Hasilnya, jejak ekologi Palembang dan sekitarnya adalah 0.591 gha. Jejak ekologi di Kota Metropolitan Palembang dan sekitarnya dibentuk oleh 4 hal, yaitu: diet dan pilihan makanan, tempat tinggal / kehidupan rumah, transportasi dan pilihan gaya hidup. Bagian terbesar diberikan oleh diet dan pilihan makanan (26,8 persen), sedangkan kontribusi terkecil disumbang oleh transportasi (24,1 persen). Dengan mempertimbangkan faktor demografi, jejak ekologis yang tinggi dimiliki oleh kelompok individu pria, berusia 3039 tahun, berpendidikan tinggi, bekerja, dan telah mendengar dan memahami perubahan iklim dan jejak ekologis. Akhirnya, jika diamati menurut jenis pemerintahan, tipe kota metropolitan memiliki jejak ekologi yang tinggi dibanding yang lain.

Katakunci: Demografi, jejak ekologi, Palembang Indonesia

\section{Introduction}

To help simplifying the description of the damage phenomenon to the earth, the concept of ecological footprint can be used. Actually this concept is not specifically built to calculate the destruction of the face of the earth. Through Ecological footprint and appropriated carrying capacity: what urban economics leaves out, Rees (1992) began to popularize the concept of ecological footprint. This concept calculates how much space (on land and water) humans need to produce the resources they need including absorbing the waste they produce [1]. The calculation of the ecological footprint is carried out by calculating the number of hectares of living space (land and water) on earth that is needed by its inhabitants (human) to fulfill all of its necessities in years.

The concept of ecological footprint can be interpreted as how wasteful an individual's and society's lifestyle is in a particular country. Grooten 
et al., (2012) [2] reveals the level of wasteful use of natural resources by countries in the world. There are ten countries that have the highest ecological footprint (wasteful) when utilizing their natural resources, namely: Qatar, Kuwait, United Arab Emirates, Denmark, the United States, Belgium, Australia, Canada, the Netherlands and Ireland. In the report, it was revealed that the progress of several countries in the economic field had increased the ecological footprint per capita by 65 percent since 1961. This means that an increase in the ecological footprint was in line with the economic progress of a country. Furthermore, the Living Planet Report noted that the lifestyle of the Qatarians needs to be supported by natural resources of up to 11.68 hectares, the Japanese people spend 4.17 hectares and the Indonesians only have 1.13 hectares. Meanwhile, the lifestyle of the people of Bangladesh and Timor Leste is fulfilled with only 0.66 and 0.47 hectares.

This ecological footprint can be used in a variety of analytical units, ranging from the smallest to the largest. Lambrechts and Liedekerke (2014) argue that many ecological footprint analyzes have been carried out in various entities, both private, public, and non-governmental organizations, including educational institutions at various levels such as: personal, organizational, urban, regional, and state [3]. This study calculates the ecological footprint in Palembang and its surroundings according to demographic factors and regional government (metropolitan city and others).

\section{Methods}

To investigate the general pattern of ecological footprint and its determinants based on the respondents' reports, a survey was launched in October 2017. The questionnaire included six different parts. The first part collected information about the diet and food choices. The second part collected information about shelter/home life. Third part up to fourth collects information about: transportation, lifestyle choices (Table 1).

Table 1 Survey items used for calculate the ecological footprint

\begin{tabular}{|c|c|c|}
\hline Concept & Survey items & Scale \\
\hline $\begin{array}{l}\text { Diet and Food } \\
\text { Choices }\end{array}$ & $\begin{array}{l}\text { How often do you eat } \\
\text { meat or other animal } \\
\text { products (i.e. milk, } \\
\text { cheese, eggs)? }\end{array}$ & $\begin{array}{ll}1 & \text { Never. I'm vegan. } \\
2 & \text { I don't eat meat or eggs but I eat } \\
& \text { some dairy products } \\
3 & \text { I don't eat meat, but I eat eggs and dairy products } \\
4 & \text { I eat meat and other animal products several times a week. } \\
5 & \text { I eat meat and other animal products everyday }\end{array}$ \\
\hline & $\begin{array}{l}\text { How often do you eat } \\
\text { fast food or eat out } \\
\text { (this includes the } \\
\text { school cafeteria)? }\end{array}$ & $\begin{array}{ll}1 & \text { Never } \\
2 & \text { Rarely (a couple of times a month) } \\
3 & \text { Sometimes (once or twice a week) } \\
4 & \text { Often (a few times a week) } \\
5 & \text { Almost every day or every day } \\
\end{array}$ \\
\hline & $\begin{array}{l}\text { How often do you eat } \\
\text { processed foods (i.e. } \\
\text { frozen foods or } \\
\text { prepackaged foods)? }\end{array}$ & $\begin{array}{ll}1 & \text { Never } \\
2 & \text { Rarely (a couple of times a month) } \\
3 & \text { Sometimes (once or twice a week) } \\
4 & \text { Often (a few times a week) } \\
5 & \text { Almost every day or every day } \\
\end{array}$ \\
\hline & $\begin{array}{l}\text { How often do you buy } \\
\text { food that was } \\
\text { produced or grown } \\
\text { locally? }\end{array}$ & $\begin{array}{ll}1 & \text { Never } \\
2 & \text { Rarely (a couple of times a month) } \\
3 & \text { Sometimes (once or twice a week) } \\
4 & \text { Often (a few times a week) } \\
5 & \text { Almost every day or every day } \\
\end{array}$ \\
\hline & $\begin{array}{l}\text { How often do you } \\
\text { drink bottled mineral } \\
\text { water? }\end{array}$ & $\begin{array}{ll}1 & \text { Never, I use my own water bottle } \\
2 & \text { Rarely (a couple of times a month) } \\
3 & \text { Sometimes (once or twice a week) } \\
4 & \text { Often (almost every day) } \\
5 & \text { I drink more than one bottle a day }\end{array}$ \\
\hline Shelter/Home Life & $\begin{array}{l}\text { I turn off the lights } \\
\text { when I leave a room }\end{array}$ & $\begin{array}{ll}1 & \text { Always } \\
2 & \text { Usually } \\
3 & \text { Sometimes (about half and half) } \\
4 & \text { Almost never } \\
5 & \text { Never }\end{array}$ \\
\hline
\end{tabular}


How often do you classify your garbage from recyclables?
1 I never put recyclable items in the garbage

2 I rarely put recyclable items in the garbage (not more than once a week)

3 I occasionally put recyclable items in the garbage (a few times a week)

4 I frequently put recyclable items in the garbage (every day or almost every day)

5 I don't recycle at all

How long do you usually take a shower?

1 Less than 5 minutes

25 to 9 minutes

310 to 15 minutes

$4 \quad 15$ to 20 minutes

520 minutes or longer

When you shower do 1 Yes

you stop the water 5 No

while shaving, wa-

shing your hair, etc?

Which statement best describes you?

1 When it $\mathrm{s}$ too hot or cold in the house, I change my clothing rather than turn the heat or air conditioning up.

5 When it ${ }^{\text {ee }}$ too hot or cold in the house, I turn up the heat or the air conditioning rather than change my clothing

Transportation Which method of 1 I walk
transportation you 2 I ride my bike

USUALLY use to 3 I take public transportation (bus, subway, etc.) or a school bus school or work? $\quad 4$ I get a ride with one or more of my friends

5 My parents drive me or I drive myself

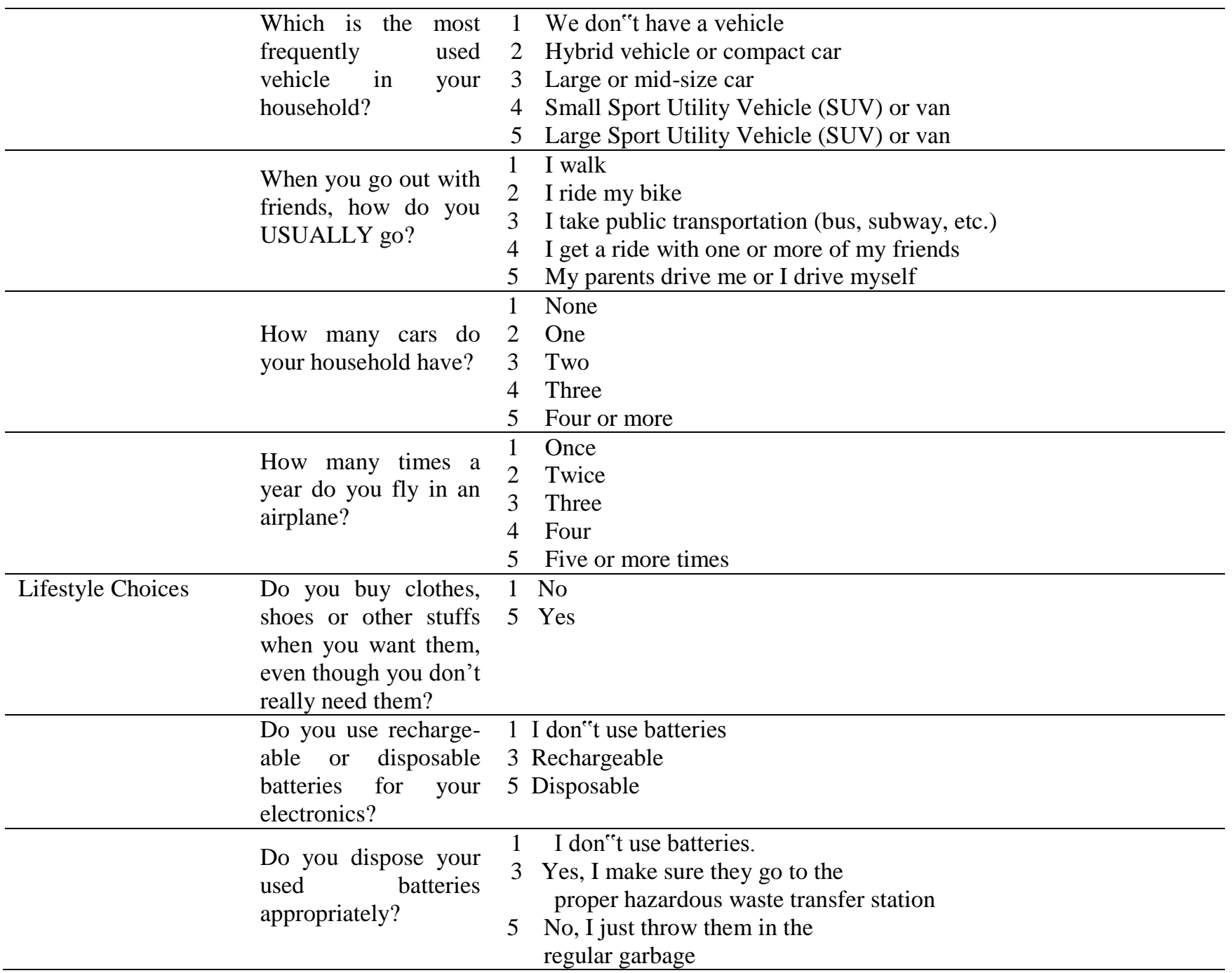




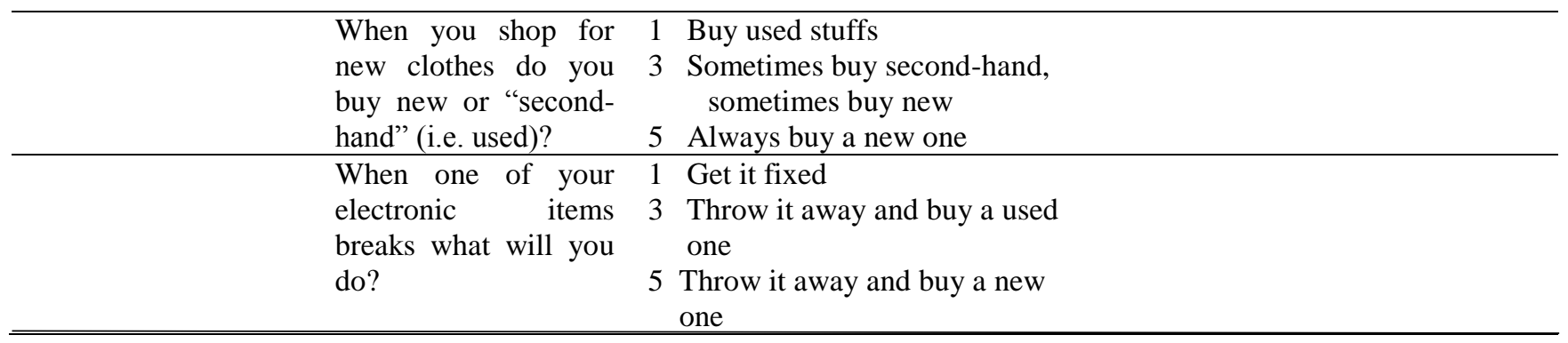

Note: As many survey questions were in matrix format, wording for items in this table been modified to show the question stems.

Meanwhile table 2 presents the concept of demographics and government along with survey items and scale: age, gender, education experienceincluding knowledge and understanding or not about climate change and ecological footprint, daily activities, marital status, status in the household and the number of family members and local government. Ecological footprint is calculated by totaling the 20 component scores. The overall score ranges from 1 to 5. Weighting for each behavior adopted by Turner, T. (2008) by adding all the values and dividing it by 100 in units of hectares [4].

Table 2 Survey items used for profiling

\begin{tabular}{|c|c|c|}
\hline Concept & Survey items & Scale \\
\hline \multirow[t]{30}{*}{ Demographics } & \multirow[t]{5}{*}{ Age: } & $1<=19$ \\
\hline & & $2 \quad 20-29$ \\
\hline & & $3 \quad 30-39$ \\
\hline & & $4 \quad 40-49$ \\
\hline & & $550+$ \\
\hline & \multirow[t]{2}{*}{ Gender: } & $1 \quad$ Male \\
\hline & & 2 Female \\
\hline & \multirow[t]{5}{*}{ Education } & 1 Don't finish school \\
\hline & & 2 Elementary school \\
\hline & & 3 Middle School \\
\hline & & 4 High School \\
\hline & & 5 University \\
\hline & \multirow{3}{*}{ Daily activities } & 1. Work \\
\hline & & 2. School / college \\
\hline & & 3. Household task \\
\hline & \multirow{2}{*}{ Marital status } & 1. Marry \\
\hline & & 2. Others \\
\hline & \multirow{2}{*}{ Status in the household } & 1. Head of household \\
\hline & & 2. Others \\
\hline & \multirow{5}{*}{$\begin{array}{l}\text { The number of family members (eating } \\
\text { from the same kitchen) ... person }\end{array}$} & 12 \\
\hline & & 23 \\
\hline & & 34 \\
\hline & & 45 \\
\hline & & $56+$ \\
\hline & \multirow{2}{*}{$\begin{array}{l}\text { Have you ever heard of climate change } \\
\text { events? }\end{array}$} & 1 Yes \\
\hline & & 2 No \\
\hline & \multirow{2}{*}{$\begin{array}{l}\text { Do you understand in detail about climate } \\
\text { change? }\end{array}$} & 1 Yes \\
\hline & & 2 No \\
\hline & \multirow{2}{*}{$\begin{array}{l}\text { Have you ever heard of ecological } \\
\text { footprint? }\end{array}$} & 1 Yes \\
\hline & & 2 No \\
\hline \multirow[t]{2}{*}{ Government } & \multirow[t]{2}{*}{ Local government } & 1 Metropolitan \\
\hline & & 2 Other \\
\hline
\end{tabular}

Note: As many survey questions were in matrix format, wording for items in this table been modified to show the question stems.

\section{Results and Discussion}

Table 3 presents the ecological footprint in Palembang and its surroundings with various values such as ecological footprint according to demographic conditions and levels of government. The average ecological footprint in Palembang Metropolitan and its surroundings is 0.591 global hectares (gha). 
Table 3. Ecological footprint in Palembang and around areas

\begin{tabular}{lccrcc}
\hline Variable & Obs & Mean & Std. Dev. & Min & Max \\
\hline $\begin{array}{l}\text { Ecological } \\
\text { footprint }\end{array}$ & 715 & 0.591 & 0.086 & 0.26 & 0.86 \\
\hline
\end{tabular}

This figure is slightly below the ecological footprint of Bangladesh (0.620 gha) and Afghanistan (0.620 gha) but above the East Timor ecological footprint (0.440 gha). The ecological footprint in Palembang Metropolitan and its surroundings is formed by 4 things, namely: diet and food choices, shelter/home life, transportation and lifestyle choices (figure 1). The largest portion is given by diet and food choices (26.8 percent), while the smallest contribution is contributed by transportation (24.1 percent). This condition is contrary to ecological trace conditions in Canada. Like the findings of Isman et al. (2018) at Canada, food contributes the smallest (5 percent) compared to transportation (25 percent) and housing (14 percent) [5]. Those findings are similar to those in Pakistan. Conclusion by Rashid et. al (2018) show that transportation is a major contributor to the ecological footprint in Pakistan [6]. The high contribution of food and the choice of food for the ecological footprint in Palembang Metropolitan and its surroundings is an indicator of people who still spend resources to meet basic needs. However, dietary patters are among the key drivers of the region's ecological deficit. Therefore, a diet that is sufficient in calories and changes in diet can reduce footprints [7].

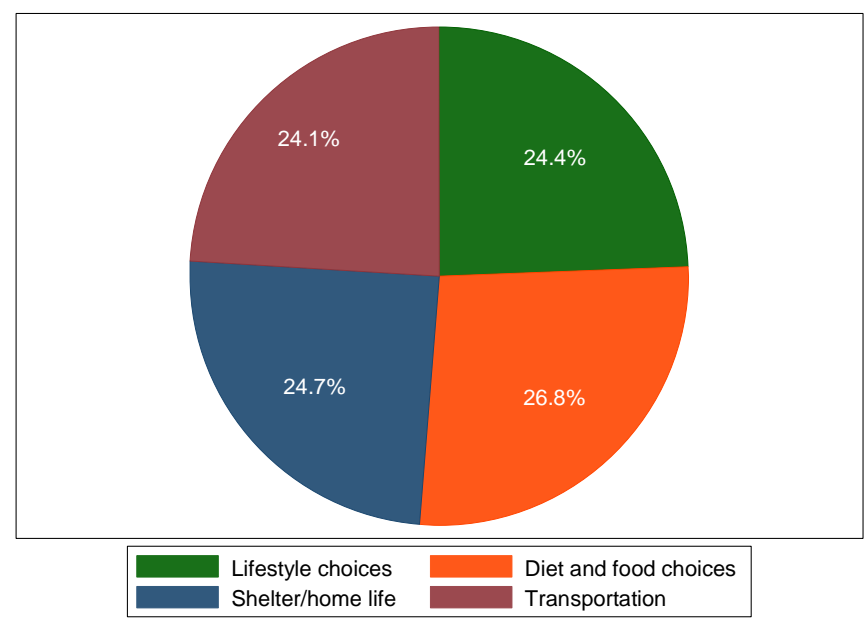

Figure 1. The proportion of 4 elements in composing an ecological footprint

According to Grooten et al. (2012) the ecological footprint is very dependent on the level of development and wealth [2]. Wealth is related to what is consumed, what products are purchased and the pattern of travelling. The habit of consuming meat or other animal products such as milk, cheese and eggs determines the high ecological footprint. Similarly, consumption of fast food and processed foods. Wang et al. (2018) uses the term ecological footprint intensity, which is used to represent the resource consumption level matching to unit economic output [8].

Table 4 describes the ecological footprint in in Palembang Metropolitan and its surroundings with various variations such as ecological footprint according to age, gender, educational experience, daily activities, marital status, status in the household, the number of family members, knowledge of climate change and ecological footprint, and understanding of climate change and ecological footprint. According to age groups, the highest ecological footprint is owned by the 30-39 age group. While the lowest is done by the age group $50+$. This phenomenon may be related to the condition of the 30-39 age group as the most active group in diet and choice of food, shelter / home life, transportation and lifestyle choices. The opposite condition occurs in groups aged 50+. This situation is in accordance with Bleys et al., (2018) description which states that pro-environmental behavior and / or including ecological footprint are shown to be related to gender, age, income, family composition, and whether the individual lives in an urban or a rural area [9].

The ecological footprint of male in Palembang and its surroundings is higher than that of female. This finding is in line with the findings of Iris et al., (2018) was recorded that the proportion of female who do not eat meat, fish, dairy products or eggs, or rarely eat these food stuffs and chose the EF-products is profoundly higher than the men [10]. Other than that, in terms of gender, male are more dependent on cars whereas female employ a broader variety of transportation modes [11]. Furthermore, observing the ecological footprint according to education found that - except those who are not educated - the ecological footprint is directly proportional to education. The higher the education the higher the ecological footprint. This finding is different from the findings of Iris et al., (2018) where proportion of the respondents from the lowest education level, who chose the EF-product, is lower than the proportion of participants from higher education levels [10]. This finding shows the difference in meaning about education. In an environmental perspective including the ecological footprint in Palembang and its surroundings, education has not brought awareness to care for the environment. Education is defined as limited to increasing of knowledge alone. 
Table 4. Ecological footprint and demographic factors in Palembang and surrounding areas

\begin{tabular}{|c|c|c|c|c|c|}
\hline Variable & Obs & Mean & Std. Dev. & Min & Max \\
\hline \multicolumn{6}{|l|}{ Demography } \\
\hline \multicolumn{6}{|l|}{ Age } \\
\hline - $<=19$ & 271 & 0.5933948 & 0.0762665 & 0.35 & 0.83 \\
\hline - $20-29$ & 188 & 0.5929787 & 0.0906522 & 0.28 & 0.86 \\
\hline - $30-39$ & 111 & 0.6057658 & 0.0930743 & 0.35 & 0.81 \\
\hline - $40-49$ & 97 & 0.5830928 & 0.0902931 & 0.26 & 0.80 \\
\hline - $50+$ & 40 & 0.5572500 & 0.0835736 & 0.40 & 0.74 \\
\hline \multicolumn{6}{|l|}{ Gender } \\
\hline - Male & 289 & 0.5939100 & 0.0832350 & 0.26 & 0.82 \\
\hline - Female & 424 & 0.5891274 & 0.0878880 & 0.28 & 0.86 \\
\hline \multicolumn{6}{|l|}{ Education experience } \\
\hline - Don't finish school & 1 & 0.6400000 & & 0.64 & 0.64 \\
\hline - Elementary school & 5 & 0.4880000 & 0.0637966 & 0.38 & 0.54 \\
\hline - Middle School & 118 & 0.5744915 & 0.0774332 & 0.35 & 0.76 \\
\hline - High School & 166 & 0.5774096 & 0.0882691 & 0.28 & 0.83 \\
\hline - Universities & 415 & 0.6029157 & 0.0851536 & 0.26 & 0.86 \\
\hline \multicolumn{6}{|l|}{ Daily activities } \\
\hline - Work & 247 & 0.6030769 & 0.0896801 & 0.26 & 0.82 \\
\hline - School/ college & 394 & 0.5923604 & 0.078727 & 0.35 & 0.86 \\
\hline - Household task & 73 & 0.5415068 & 0.0955637 & 0.28 & 0.78 \\
\hline \multicolumn{6}{|l|}{ Marital status } \\
\hline - Married & 254 & 0.5911024 & 0.0889706 & 0.35 & 0.82 \\
\hline - Others & 446 & 0.5941031 & 0.0799521 & 0.35 & 0.86 \\
\hline \multicolumn{6}{|l|}{ Status in the household } \\
\hline - Head of household & 123 & 0.6089431 & 0.0851788 & 0.35 & 0.82 \\
\hline - Others & 573 & 0.5902094 & 0.0821390 & 0.35 & 0.86 \\
\hline \multicolumn{6}{|l|}{ The number of family members } \\
\hline - 2 & 82 & 0.5903659 & 0.0824987 & 0.38 & 0.81 \\
\hline - 3 & 102 & 0.5925490 & 0.0933712 & 0.26 & 0.82 \\
\hline - 4 & 177 & 0.5830508 & 0.0863710 & 0.28 & 0.86 \\
\hline - 5 & 186 & 0.5929032 & 0.0839959 & 0.32 & 0.80 \\
\hline - $6+$ & 150 & 0.6010000 & 0.0834713 & 0.35 & 0.82 \\
\hline \multicolumn{6}{|l|}{ Ever heard of climate change } \\
\hline - Yes & 697 & 0.5915925 & 0.0858890 & 0.26 & 0.86 \\
\hline - $\mathrm{No}$ & 18 & 0.5533333 & 0.0956710 & 0.42 & 0.71 \\
\hline \multicolumn{6}{|l|}{ Understanding climate change } \\
\hline - Yes & 625 & 0.5932160 & 0.0852338 & 0.26 & 0.86 \\
\hline - No & 70 & 0.5801429 & 0.0902090 & 0.35 & 0.76 \\
\hline \multicolumn{6}{|l|}{ Ever heard of ecological footprint } \\
\hline - Yes & 307 & 0.5935505 & 0.0851341 & 0.26 & 0.86 \\
\hline - No & 408 & 0.5884314 & 0.0871779 & 0.35 & 0.82 \\
\hline \multicolumn{6}{|l|}{ Understanding ecological footprint } \\
\hline - Yes & 84 & 0.5947619 & 0.0813956 & 0.28 & 0.81 \\
\hline - No & 214 & 0.5930841 & 0.0873653 & 0.26 & 0.86 \\
\hline
\end{tabular}

The ecological footprint according to daily activities decreases in sequence: work, school / college and household task. As in Indonesia, in Palembang and its surroundings, household task is associated with female. Therefore, female's ecological footprint is low in three approaches: gender, spouses of husbands and household tasks. This finding, at least, has contributed to answering the question: "Do women leave a smaller ecological footprint than men? [12]

An assumption in this paper is that the groups that have heard and understood climate change leave a smaller 'ecological footprint' than groups that have never heard and do not understand climate change. The paper also assumes that groups that have heard and understood the ecological footprint leave smaller 'ecological footprints' than groups that have never heard and do not understand the ecological footprint. But these two assumptions are not supported by evidence. In fact, groups that have heard and understood climate change and ecological footprint leave a higher 'ecological footprint' than groups that have never heard and do not understand climate change and ecological footprint. This evidence is in line with the interpretation that education has not brought awareness to care for the environment. Education is defined as limited to increasing knowledge alone. 
Table 5. Ecological footprint and government factor in Palembang and its surroundings

\begin{tabular}{lccccc}
\hline \multicolumn{1}{c}{ Variable } & Obs & Mean & $\begin{array}{c}\text { Std. } \\
\text { Dev. }\end{array}$ & Min & Max \\
\hline $\begin{array}{l}\text { Local } \\
\text { government }\end{array}$ & & & & & \\
- Metropolitant & 486 & 0.595 & 0.079 & 0.36 & 0.86 \\
- Others & 219 & 0.588 & 0.090 & 0.35 & 0.82 \\
\hline
\end{tabular}

Source: processed from primary data

The ecological footprint of Palembang as a metropolitan city is higher than the surrounding areas (table 5). According to Muñuzuri (2010) [12] the high rate of ecological footprint in urban or metropolitan areas is mainly caused by high consumption of transportation, traffic congestion, lack of parking and uncontrolled pollution. Geng et al. (2014) [13] added that the high ecological footprint in metropolitan areas is caused by industries that are not well managed. In a study comparing the conditions of the ecological footprint of the two sister cities between ShenyangChina and Kawasaki-Japan, the data analysis was based on data from 1997 to 2009 . The results showed that the Shenyang ecological footprint experienced a significant increase, while the figures Kawasaki is quite stable, even though the per capita income figure in Shenyang is much lower than Kawasaki. To further enhance sustainable development, Shenyang must collaborate with Kawasaki, learn about the economic experience of Kawasaki city and other environmental management experiences. In addition, Shenyang must also learn from other leading cities and try to optimize its industrial and energy structure through increasing awareness of the citizens' environment so that they can move towards a more sustainable development direction.

In the view of Toth and Szigeti (2016) the ecological footprint is always related to the concentration of the population [14]. Most of the population chooses to live outside the forest area so that the ecological footprint in the forest area is lower than outside the forest area. In other words, the lifestyle and consumption culture in the area around the forest needs to be maintained and even disseminated. Palembang and its surroundings are river metropolitan cities. Ecological footprint along the river area cannot be separated from development. Li and Wen (2017) propose the development of ecological corridors along the watershed by giving attention to the cooperation of all stakeholders [15]. By strengthening collaboration among stakeholders, the development of ecological corridors will save many things which will ultimately save natural resources. Referring to the opinion of Comino et al., (2017) that the type of field (land) and cultivation system are determinants of erosion and vegetation [16]. Thus, awareness of the impact of disasters is very important. The implication when awareness of the impact of disaster reduction (eg. erosion) can be a reference that can prevent erosion. This kind of awareness will indirectly make a low ecological footprint.

Analogous to ethnocentric which is very popular among anthropologists and sociologists, this paper uses metropolitan-centric or metro-centric to explain the ecological footprint phenomenon. Metropolitan is synonymous with the center of government, business, entertainment and lifestyle. That is, in a sociology approach, an ecological footprint can be interpreted as entity a marked by an increase in energy. Research conducted by Charfeddine and Mrabet (2017) [7] in oilproducing Middle Eastern and North African countries shows that energy use has exacerbated the ecological footprint while real Gross Domestic Product per capita shows an inverted U-shaped relationship with the ecological footprint following the Kuznets environmental curve [17]

This means that in the early days of development and the development process, the ecological footprint will increase due to energy use and pollution. To a certain extent, development is considered successful because it has increased income, easy access to health, education and employment. In this condition, awareness of the importance of a healthy environment will grow, and in time it will process and result in a decrease in ecological footprint. Following the thinking of Pellizzoni (2016) which states that the concept of matter of environmental sociology is allegedly still in a dormant state, the ecological footprint can contribute to clarifying the concept of matter of environmental sociology [18]. The phenomenon of ecological footprint in city countries like Taiwan can be a mirror for reflection. Wang et al., (2012) stated that in 2007 due to the consumptive lifestyle of Taiwanese people, the provision of natural resources normally consumed by Taiwanese people needed to be supported by 42 times the area of Taiwan [19]. Reflecting on the condition of Taiwan's ecological footprint in 2007 and the existence of a similar pattern on the ecological footprint on Palembang. Consumptive culture needs to be transformed, because consumption is a must. Perhaps moderate consumption as exemplified by the preceding generation needs to be echoed again so that it can create ecological security. According to Chu et al., (2017) ecological security can be achieved if there is a balance between economic development and ecosystem conservation [20]. The ecological security of the Beijing-Tianjin-Hebei (BTH) region between 1995 and 2010 that cannot be maintained based on the ecological footprint of the BTH region which increased to 1.77 times is a good example. Using the phenomenon of ecological security in the Beijing-Tianjin-Hebei region as a material for sociological reflection will have implications for the importance of safeguarding unstable land to avoid frightening environmental disasters.

From sociologists such as Davidson and Stedman (2017), inverted $U$ shows the need to reflect for improvement [21]. In the language of Qur'an the inverted $\mathrm{U}$ - can be interpreted as returning to the right 
path after doing damage on land and at sea (QS, ArRuum, 41). The process of returning to the right path can be started by referring to the ecological footprint itself which functions as a mirror. As shown in Figure 1 , the priority of change can be started from the pattern of eating and drinking. Diet and food choices are the biggest element in forming an ecological footprint that is $26.8 \%$, followed by shelter/home life (24.7\%), lifestyle choices (24.4\%) and transportation (24.1\%). The basis for change can use one of the ideas of the Creator like "... eat and drink, and do not overdo it. Indeed Allah does not like the people who commit excess " (Surat al-A'raaf: 31). By using academic language, the scriptures can be positioned as scientific law. Davis and Carter (2009) concluded that overeating has similarities with drug addiction [22]. This conclusion is based on comparable clinical trials, the biological mechanisms they have and the evidence that the two disorders share the same characteristics. By placing paragraph 31 of Surat Al A'raaf as scientific law, it can be derived from other aspects, not only applied to food, but to all natural resources such as energy, water and air. Thus, the recommendation to use water as needed or use enough energy will be a social norm.

The use of the holy verse as a behavioral reference is still well preserved at all ages, including young people. Arli et al., (2017) observed the impact of religiosity on consumer ethics among young people [22]. The results of his research mention that young people understand the boundary between legal and illegal behavior. But if the legal and illegal boundaries are not clear, they use religious law as a hand. This means, religious practices are still strong among young people. Reflecting on the religiosity of these young people, then using religious ideas among young people as a reference to maintain conditions so that the ecological footprint remains low is not impossible. The basic idea is to consume natural resources without exaggeration as outlined by the holy verse. The link between religiosity and the environment is still not a popular topic and very few in number. Among those few, Alipour and Forouzan (2017) examined the environmental impact of popular religious tourism in Mashhad, Iran [23]. In particular, this study assessed the spatial pattern of environmental impacts from religious tourism with a focus on the area around the sanctuary. As a result, although religious tourism has resulted in environmental improvements, it is limited to areas that immediately surround the sanctuary, and this improvement does not cover the entire city. Thus, incorporating ideas about the environment needs to be included in discussions about religious life. Hopefully, the growing awareness of environmental conditions will reduce the ecological footprint.

\section{Conclusion}

The average ecological footprint in Palembang Metropolitan and its surroundings is 0.591 global hectares (gha). This figure is slightly below the ecological footprint of Bangladesh (0.620 gha) and Afghanistan (0.620 gha) but above the East Timor ecological footprint (0.440 gha). The ecological footprint in Palembang Metropolitan and its surroundings is formed by 4 things, namely: diet and food choices, shelter/home life, transportation and lifestyle choices. The largest portion is given by diet and food choices (26.8 percent), while the smallest contribution is contributed by transportation (24.1 percent). According to age groups, the highest ecological footprint is owned by the age of 30-39. The ecological footprint of male in Palembang and its surroundings is higher than that of female. Observing the ecological footprint according to education found that - except those who are not educated - the ecological footprint is directly proportional to education. The higher the education the higher the ecological footprint. The ecological footprint according to daily activities decreases in sequence: work, school / college and household task. In fact, groups that have heard and understood climate change and ecological footprint leave a higher 'ecological footprint' than groups that have never heard and do not understand climate change and ecological footprint. Finally, the ecological footprint of Palembang as a metropolitan city is higher than the others.

\section{References}

[1] Rees, W. E. (1992). Ecological footprints and appropriated carrying capacity: what urban economics leaves out. Environment and urbanization, 4(2), 121-130.

[2] Grooten, M., Almond, R., \& McLellan, R. (Eds.). (2012). Living planet report 2012: Biodiversity, biocapacity and better choices. World Wide Fund for Nature.

[3] Lambrechts, W., \& Van Liedekerke, L. (2014). Using ecological footprint analysis in higher education: Campus operations, policy development and educational purposes. Ecological Indicators, 45, 402-406.

[4] Turner, T. How Big is My Ecological Footprint? In Grant, T., \& Littlejohn, G. (Eds.). (2005). Teaching Green--The Elementary Years: Hands-on Learning in Grades K-5. New Society Publishers.

[5] Isman, M., Archambault, M., Racette, P., Konga, C. N., Llaque, R. M., Lin, D., ... \& OuelletPlamondon, C. M. (2018). Ecological Footprint assessment for targeting climate change mitigation in cities: A case study of 15 Canadian cities according to census metropolitan areas. Journal of Cleaner Production, 174, 1032-1043. 
[6] Rashid, A., Irum, A., Malik, I. A., Ashraf, A., Rongqiong, L., Liu, G., ... \& Yousaf, B. (2018). Ecological footprint of Rawalpindi; Pakistan's first footprint analysis from urbanization perspective. Journal of Cleaner Production, 170, 362-368.

[7] Charfeddine, L., \& Mrabet, Z. (2017). The impact of economic development and social-political factors on ecological footprint: A panel data analysis for 15 MENA countries. Renewable and Sustainable Energy Reviews, 76, 138-154.

[8] Wang, Z., Yang, L., Yin, J., \& Zhang, B. (2018). Assessment and prediction of environmental sustainability in China based on a modified ecological footprint model. Resources, Conservation and Recycling, 132, 301-313.

[9] Bleys, B., Defloor, B., Van Ootegem, L., \& Verhofstadt, E. (2018). The environmental impact of individual behavior: self-assessment versus the ecological footprint. Environment and Behavior, 50(2), 187-212.

[10] Iris, G., Abraham, H., \& Doron, K. (2018). Examination of the relationship between dietary choice and consumer preferences for sustainable near-food products in Israel. Journal of Cleaner Production, 197, 1148-1158.

[11] Soltani, A., Pojani, D., Askari, S., \& Masoumi, H. E. (2018). Socio-demographic and built environment determinants of car use among older adults in Iran. Journal of Transport Geography, 68, 109-117

[12] Johnsson-Latham, G. (2006). Initial study of lifestyles, consumption patterns, sustainable development and gender: Do women leave a smaller ecological footprint than men?. Swedish Ministry of Sustainable Development.

[13] Geng, Y., Zhang, L., Chen, X., Xue, B., Fujita, T., \& Dong, H. (2014). Urban ecological footprint analysis: a comparative study between Shenyang in China and Kawasaki in Japan. Journal of cleaner production, 75 , 130-142.

[14] Toth, G., \& Szigeti, C. (2016). The historical ecological footprint: From over-population to overconsumption. Ecological Indicators, 60, 283-291.
[15] Li, T., \& Wen, X. (2017). Local ecological footprint dynamics in the construction of the Three Gorges Dam. Resources, Conservation and Recycling.

[16] Comino, J. R., Senciales, J. M., Ramos, M. C., Martínez-Casasnovas, J. A., Lasanta, T., Brevik, E. C., Ries J.B. \& Sinoga, J. R. (2017). Understanding soil erosion processes in Mediterranean sloping vineyards (Montes de Málaga, Spain). Geoderma, 296, 47-59.

[17] Panayotou T. (2003) Chapter 2: economic growth and the environment. Economic survey of Europe, No: 2; 2003. www.unece.org/fileadmin/DAM/ead/pub/032/ 032_c2.pdf

[18] Pellizzoni, L. (2016). Catching up with things? Environmental sociology and the material turn in social theory. Environmental Sociology, 2(4), 312321.

[19] Wang, B. C., Chou, F. Y., \& Lee, Y. J. (2012). Ecological footprint of Taiwan: A discussion of its implications for urban and rural sustainable development. Computers, Environment and Urban Systems, 36(4), 342-349.

[20] Chu, X., Deng, X., Jin, G., Wang, Z., \& Li, Z. (2017). Ecological security assessment based on ecological footprint approach in Beijing-TianjinHebei region, China. Physics and Chemistry of the Earth, Parts A/B/C, 101, 43-51.

[21] Davidson, D. J., \& Stedman, R. C. (2017). Calling forth the change-makers: Reflexivity theory and climate change attitudes and behaviors. Acta Sociologica, 0001699317693065.

[22] Arli, D., Tjiptono, F., Lasmono, H, \& Anandya, D. (2017). Do consumer ethics and consumer religiousness evolve across time? Insights from Millennials in Indonesia. Young Consumers, 18(4), 329-347.

[23] Alipour, H., Olya, H. G., \& Forouzan, I. (2017). Environmental Impacts of Mass Religious Tourism: From Residents' Perspectives. Tourism Analysis, 22(2), 167-183. 